\title{
Organic Ginger (Zingiber officinale Rosc.) Development in a Short Temperate Growing Season: Effect of Seedling Transplant Type and Mycorrhiza Application
}

\author{
Lurline Marsh*, Fawzy Hashem, Brett Smith \\ Department of Agriculture, Food and Resource Sciences, University of Maryland Eastern Shore, Princess Anne, MD, USA \\ Email: *lemarsh@umes.edu, fmhashem@umes.edu, bdsmith@umes.edu
}

How to cite this paper: Marsh, L., Hashem, F. and Smith, B. (2021) Organic Ginger (Zingiber officinale Rosc.) Development in a Short Temperate Growing Season: Effect of Seedling Transplant Type and Mycorrhiza Application. American Journal of Plant Sciences, 12, 315-328.

https://doi.org/10.4236/ajps.2021.123020

Received: January 31, 2021

Accepted: March 16, 2021

Published: March 19, 2021

Copyright $\odot 2021$ by author(s) and Scientific Research Publishing Inc. This work is licensed under the Creative Commons Attribution International License (CC BY 4.0).

http://creativecommons.org/licenses/by/4.0/ (c) (i) Open Access

\begin{abstract}
Global warming and consumer demand for medicinal plants present an opportunity to introduce ginger growth to the US Delmarva Peninsula. High tunnel and field studies were conducted to assess the development of organic ginger (Zingiber officinalis, Rosc) seedling transplants in mycorrhiza-amended soil. Transplant types were tissue culture derived with less than three tillers (TCS1), three or more tillers (TCS2), and nontissue culture derived (NTCS1). Transplants were grown with or without mycorrhiza ( $2.8 \mathrm{~g}$ per plant) in a split plot design with soil amendments as main plot and transplant type as subplot. Data were collected for air temperatures, plant height, tiller number, leaf chlorophyll index (LCI), rhizome fresh weight, plant biomass, rhizome nutrients, and levels of As and $\mathrm{Pb}$. TCS2 transplants produced significantly higher, or trended to higher rhizome yield than transplants with less than three tillers, except for year two field study. The maximum rhizome fresh weight per plant was $648.3 \mathrm{~g}$ for TCS2 in high tunnel in year one. Generally, TCS2 had most tillers throughout the growing season ranging from 6.9 to 25.7 tillers per plant over three studies. Mycorrhiza had no effect on ginger height, tiller number, LCI or rhizome yield. Sustained high temperatures above $37^{\circ} \mathrm{C}$, plus high light in the field caused dieback and stunted shoot growth in year two. There were no consistent effects of mycorrhiza or transplant type on rhizome nutrient content. Content of total $\mathrm{Pb}$, As and other elements were at safe threshold levels for rhizome consumption. These results suggest that gingers grown from TCS2 transplants with at least three tillers yielded more rhizome than those grown from S1 transplants with fewer tillers. Introduction of ginger to a short season region such as the Delmarva may require consideration of environmental condition such as high temper-
\end{abstract}


ature and light to which seedling transplants may be exposed in summer.

\section{Keywords}

Seedling Transplants, Mycorrhiza, Organic Agriculture, Tissue Culture, Medicinal Plants

\section{Introduction}

Ginger is generally grown in tropical and subtropical climates such as those of Southeast Asia, its origin [1]. As a popular spice crop with medicinal and nutraceutical value [1] [2] [3], consumers demand it, and some small land holders in the USA desire to grow it as a niche crop in the less tropical, short season environment. In fact, outreach and research efforts to grow ginger have been ongoing in several eastern [4] [5] and southern states of the USA [6] [7] [8] by growing the plant in high tunnels or in the field. Ginger grows best under some shading, particularly in the seedling stage, but some production was done in direct sunlight in some countries [1] [9] [10].

As consumers' demands for organic products continue to rise [11], there is the need to adapt ginger production to organic culture. Concomitantly, there is also a problem getting reliable and consistently disease clean transplants from rhizome. The main method of propagation is from rhizome pieces called seed setts. These develop tillers after planting. However, ginger production in short growing season can be a challenge for attaining optimal rhizome production. Ginger can be harvested as young baby ginger after 3 to 4 months of transplanting. Typically, ginger takes $8-10$ months to produce mature rhizomes after planted from setts [8]. Therefore, there is a need to determine other types of propagation materials and growing medium amendments that can potentially accelerate development of the crop in organic conditions in short growing seasons. One type of propagation material is seedlings with developed shoots/tillers, and this is rarely done or studied for organic culture. The only report found in the literature was one that included two sprout transplants and single sprout transplants in a non-organic system [12]. Since the number of tillers is positively correlated with rhizome production [1], this may be an approach to get a head start on plant development. With respect to growing media amendments, there is evidence that some such as composts [13] and microorganisms like Azospirillum and mycorrhiza [14] [15] [16] [17] have an effect on the yield of ginger grown from setts under conventional conditions or organic. Vesicular arbuscular mycorrhiza (VAM) fungi form a symbiotic relationship with host plants and, thus, support soil health and plant nutrition in organic agriculture [18] [19] [20]. They also enhance plant survival and fitness through mechanisms such as increasing water and nutrient uptake by extending the function of their root system and transporting nutrients to plants [21] [22]. In contrast to the many studies on the use of mycorrhiza in conventional ginger development, there is none 
for organic that also includes the use of seedling transplants in different stages, whether tissue cultured or nontissue cultured. Tissue culture of apical bud segments has been an established method to produce clean seedling explants in ginger [23] [24] [25]. The objectives of this study were to: 1) Compare the development of organic transplanted tissue cultured and nontissue cultured ginger of different tiller stages in mycorrhiza and non-mycorrhiza amended soil in high tunnel and field conditions, and 2) Assess the rhizome nutrient, lead and arsenic content of the organic ginger.

\section{Materials and Methods}

\subsection{Experimental Sites}

All high tunnels and field experiments were conducted at the University of Maryland Eastern Shore Agriculture Experiment Station located in Princess Anne, MD., USA $\left(38^{\circ} 12^{\prime} \mathrm{N} 75^{\circ} 42^{\prime} \mathrm{W}\right)$, following the National Organic Program guidelines [26]. The certified organic field sites had a sandy loam soil and phosphorus soil levels were high, $300-400 \mathrm{ppm}$, due to previous extensive poultry manure application from the local chicken industry over many years.

\subsection{Year 1 High Tunnel Study}

Yellow ginger rhizomes were purchased from a local grocery store and used for both the tissue culture (TC) and the nontissue cultured (NTC) studies. The axillary buds of rhizomes were used to aseptically regenerate clean tissue plantlets as follows. Buds were cultured in Murashige and Skoog medium supplemented with indole acetic acid $(0.5 \mathrm{mg} / \mathrm{L})$, benzyl amino purine $(0.1 \mathrm{mg} / \mathrm{L})$, Gamborg's B5 vitamin $(1 \mathrm{~mL} / \mathrm{L})$, and sucrose $(30 \mathrm{~g} / \mathrm{L})$ (Phytotechnology Laboratories, Inc., Overland Park, Kans., USA. In spring 2011 plantlets were acclimated in a chamber at $28^{\circ} \mathrm{C}$, then transferred to organic growing medium (Sungari Sunshine Mix \#1 Organic Planting Mix, Sungro Horticulture, Agawan, Mass., USA) in 11.4-cm plastic pots in a greenhouse to develop tillers. The NTC seedlings were established directly from Yellow ginger rhizome using the following procedure. Rhizomes were rinsed and surface sterilized with $10 \%$ bleach before being placed in $27.9 \times 54.6 \mathrm{~cm}$ black plastic trays/flats (Hummert International, Earth City, MO) where they were covered and kept in a growth chamber at $28^{\circ} \mathrm{C}$. Once buds formed, rhizomes were cut into $5 \mathrm{~cm}$ - size- pieces containing one bud each and planted into $11.4 \mathrm{~cm}(11.4 \mathrm{~L} \times 11.4 \mathrm{~W} \times 8.3 \mathrm{H})$ plastic pots containing Sunshine organic mix, similar to the ones for tissue culture (TC). Transplants were kept in the greenhouse until transplanted in the high tunnel. The TC and nontissue culture derived seedlings (NTC) were grouped according to their development as S1 (fewer than three tillers) or S2 (three or more tillers) resulting in three separate sets of seedlings: NTCS1, TCS1, and TCS2. Transplants were kept in greenhouse until transplanted to raised beds in a high tunnel on certified organic site at the University of Maryland Eastern Shore Experiment Station (Princess Anne, Md., USA) on June 17, 2011. The transplants were planted $25 \mathrm{~cm}$ deep in two row-beds with rows spaced $1.25 \mathrm{~m}$ apart and plants were spaced $0.3 \mathrm{~m}$ plants 
apart. The experimental design was a split plot with mycorrhiza and non-mycorrhiza treatments as main plot and the three seedling types as the subplot, and three replications. Vesicular-arbuscular mycorrhiza (VAM) inoculant was applied to the soil around each plant at a rate of $2.8 \mathrm{~g}$ per plant. The VAM, (Glomus etunicatum) inoculum (100 spores and propagules per gram of inoculum) was provided by Becker Underwood, Inc. (Ames, Iowa, USA). Beds were drip-irrigated twice weekly throughout the growing season. Plants were fertilized with Organic Materials Review Institute (OMRI)-certified fertilizers (Phyta-Grow Big Red Blood Meal 13-0-0) (California Organic Fertilizers, Inc., Fresno, Calif., USA) at a rate of $50.48 \mathrm{~g} / \mathrm{m}^{2}$ and Sulfate of Potash Ultrafine Diamond K Fertilizer (Great Salt Lake Minerals Co., Odgen, Utah., USA) at $17.87 \mathrm{~g} / \mathrm{m}^{2}$ three times during growth.

Data were recorded on plant height, number of tillers per plant, leaf chlorophyll index (LCI), and air temperature throughout the plant growth period. The LCI was measured with a SPAD 502 chlorophyll meter manufactured by Spectrum Technologies, Incorporated, Aurora, IL. Measurements were taken from five fully expanded healthy green leaves per treatment combination per replication. Matured rhizomes were harvested on December 14, the day of the first frost (Figure 1) in tunnel, and data were collected on rhizome weights, and rhizome nutrient content. For nutrient analysis, the rhizome samples were dried at $75^{\circ} \mathrm{C}$ to constant weight, then ground in a Wiley Mill, (Wiley, and Philadelphia, PA) to pass through a 1-mm screen. Samples were submitted to A \& L Eastern Laboratories, Richmond, VA, for the analysis of 13 macro- and micro-elements: N, $\mathrm{P}, \mathrm{K}, \mathrm{S}, \mathrm{Ca}, \mathrm{Mg}, \mathrm{Na}, \mathrm{Fe}, \mathrm{Al}, \mathrm{Mn}, \mathrm{Cu}, \mathrm{Zn}$, and B.

\subsection{Year 2 High Tunnel}

The Year 1 high tunnel study was repeated in 2012 where ginger seedlings were transplanted to the organic high tunnel on June 26, 2012. Data on tiller number and plant height were collected for both the high tunnel and a field study done that year. Under the moderating temperature influence of the high tunnel with warm temperatures, the rhizomes were harvested late in fall on November 29. In addition to the rhizome nutrient analyses for 13 elements, total $\mathrm{Pb}$ and total $\mathrm{As}$ contents were also determined.

\subsection{Field Study}

In Year 2, a follow up field study was conducted where ginger seedlings were transplanted to the site on June 21, 2012. Ginger rhizomes were harvested from the field site on November 14, after the first frost. Similar data were collected in the field as those for the high tunnel that year.

\subsection{Ambient Temperature Monitoring}

Air temperature during the growing season was periodically monitored and recorded (Figure 1) using a hygrothermograph, (NovaLynx, Grass Valley, CA). 

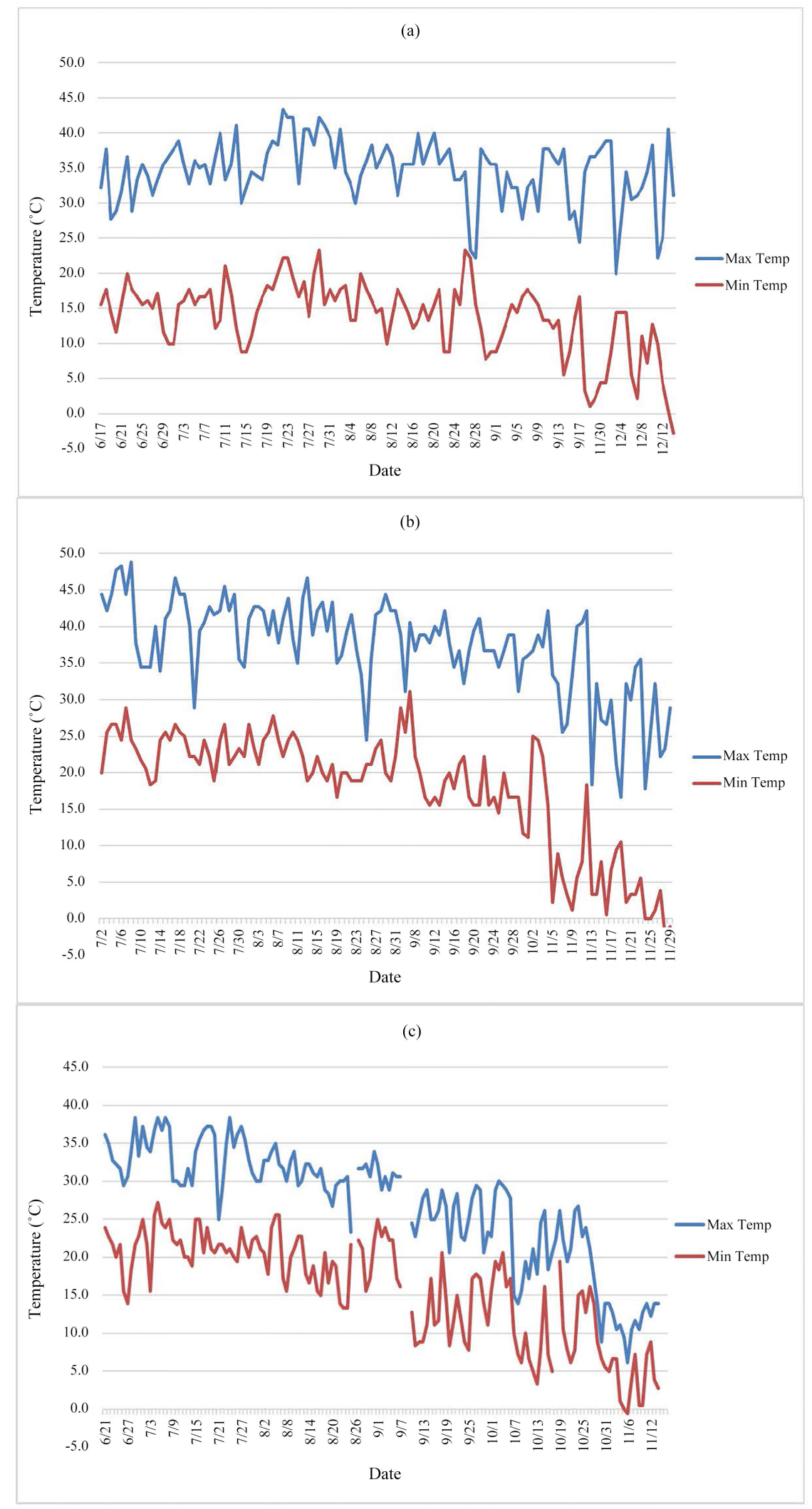

Figure 1. Maximum and minimum air temperatures for 2011 high tunnel (a), 2012 high tunnel (b) and 2012 organic field (c) during growth of ginger from transplants to rhizome harvest. 


\subsection{Statistical Analysis}

Two-way analysis of variance (ANOVA) was used to analyze the data using the SAS program (version 9.1, SAS Institute Inc., Cary, NC, USA). When interactions for variables were not significant, the data were reanalyzed to compare the main effects. The means were compared using LSD at $(P \leq 0.05)$.

\section{Results and Discussion}

\subsection{Year 1 High Tunnel Study}

Plant height and tiller number steadily increased (Table 1) during the growing period up to November 4, 2011, four and a half months after transplanting. Thereafter, the plants began to senesce, and growth ceased as the temperature decreased (Figure 1). For the first 2 months after transplanting the maximum air temperatures ranged from $27.8^{\circ} \mathrm{C}$ to $38.9^{\circ} \mathrm{C}$, except for two days in the first month and 10 days in the second month which were in the low $40 \mathrm{~s}$. For the remainder of the growing period, maximum temperatures were generally between $20.6^{\circ} \mathrm{C}$ and $38.9^{\circ} \mathrm{C}$. Minimum air temperatures ranged from $23.3^{\circ} \mathrm{C}$ to $-2.8^{\circ} \mathrm{C}$ and did not dip below freezing until December 14 due to the moderating effect of the tunnel. Mycorrhiza did not significantly promote ginger development and had no effect on plant height, tiller number or LCI within any of the sampling dates (Table 1). The available reports of the effects of mycorrhiza on ginger are for nonorganic culture and have been mixed. The research of Santos et al. [16] showed better post vitro acclimation of micro propagated ginger micro plantlets with mycorrhiza than non-mycorrhiza plants grown in greenhouse. However, the work of Silva et al. [27] with micro-propagated ginger reported mixed results when using different isolates of arbuscular mycorrhizal fungi to compare ginger shoot biomass and height against non-mycorrhiza controls. In strawberry cultivars, AM fungi applied to high phosphorus soil, fertility (Mehlich-3 extractible $\mathrm{P}=498 \mathrm{mg} \cdot \mathrm{kg}^{-1}$ ) produced mixed results, including increased daughter plants in early growth [28].

Seedling type did not affect plant height (Table 1). The more advanced TCS2 transplants consistently produced most tillers at each sampling date. When tiller production ceased, the 25.7 for TCS2 was approximately double that of each of the TCS1 and NTCS1 plants.

Leaf chlorophyll index analyses were done for each of the four separate sampling dates, 7/22, 8/23, 9/8 and 11/4 (M1, M2, M3 and M4.5) because sampling date was significant (Table 1). SPAD meter measures leaf chlorophyll index (LCI) which serves as relative measure of chlorophyll content [29]. The latter is often correlated with leaf $\mathrm{N}$ status and photosynthetic activity [30] [31]. Mycorrhiza did not have any effects on leaf chlorophyll index in this study (Table 1). However, under water stressed conditions, unlike our optimized watered study, it has been reported to increase the chlorophyll content of ginger plants over that of non-mycorrhizal plants [32]. Leaf chlorophyll index at two and three months after transplanting was highest in TCS2, perhaps indirectly due to higher photosynthesis in this active growth period (Table 1). 
Table 1. Effects of soil additive and seedling transplant type on plant height, tiller number and leaf chlorophyll index (LCI), dry shoot biomass per plant and fresh rhizome weight per plant for high tunnel organic ginger development by month (M) after transplanting in 2011 .

\begin{tabular}{|c|c|c|c|c|c|c|c|c|c|c|c|c|c|c|}
\hline \multirow[t]{3}{*}{ Treatment $^{2}$} & \multicolumn{4}{|c|}{ Height } & \multicolumn{4}{|c|}{ Tiller Number (TN)/Plant } & \multicolumn{4}{|c|}{ Leaf Chlorophyll Index (LCI) } & \multirow[t]{2}{*}{ Biomass Yield } & \multirow[t]{2}{*}{ Rhizome Yield } \\
\hline & M0 & M1 & M2 & M4.5 & M0 & M1 & M2 & M4.5 & M1 & M2 & M3 & M4.5 & & \\
\hline & \multicolumn{4}{|c|}{$\mathrm{cm}$} & \multicolumn{4}{|c|}{$\mathrm{TN}$} & \multicolumn{4}{|c|}{ LCI } & g & $\mathrm{g}$ \\
\hline \multicolumn{15}{|c|}{ Soil additive (SA) } \\
\hline VAM & 20.9 & 24.6 & 31.2 & 48.3 & 2.5 & 4.4 & 8.3 & 16.5 & 31.6 & 39.8 & 43.4 & 33.5 & 34.1 & 500.2 \\
\hline Control & 21.0 & 24.7 & 29.8 & 48.0 & 2.9 & 5.1 & 9.0 & 17.7 & 30.8 & 38.5 & 43.3 & 32.4 & 30.0 & 481.7 \\
\hline SA & NS & NS & NS & NS & NS & NS & NS & NS & NS & NS & NS & NS & NS & NS \\
\hline \multicolumn{15}{|c|}{ Seedling Type (S) } \\
\hline NTCS1 & 21.4 & 26.1 & 33.6 & 45.3 & $1.4 \mathrm{~b}^{\mathrm{y}}$ & $3.3 \mathrm{~b}$ & $6.0 \mathrm{~b}$ & $11.8 \mathrm{~b}$ & 32.0 & $38.8 \mathrm{ab}$ & $41.1 \mathrm{~b}$ & 31.6 & $20.6 \mathrm{~b}$ & $375.8 \mathrm{~b}$ \\
\hline TCS1 & 19.0 & 22.1 & 31.1 & 47.7 & $2.1 \mathrm{~b}$ & $3.5 \mathrm{~b}$ & $6.3 \mathrm{~b}$ & $13.8 \mathrm{~b}$ & 30.3 & $36.7 \mathrm{~b}$ & $44.4 \mathrm{a}$ & 31.3 & $26.4 \mathrm{ab}$ & $448.6 \mathrm{~b}$ \\
\hline TCS2 & 22.5 & 25.7 & 26.8 & 51.4 & $4.4 \mathrm{a}$ & $7.6 \mathrm{a}$ & $13.5 \mathrm{a}$ & $25.7 \mathrm{a}$ & 31.4 & $41.8 \mathrm{a}$ & $44.6 \mathrm{a}$ & 35.9 & $49.2 \mathrm{a}$ & $648.3 a$ \\
\hline S & NS & NS & NS & NS & $* * *$ & $* * *$ & $* * *$ & $* * *$ & NS & * & $* *$ & NS & * & $* *$ \\
\hline
\end{tabular}

${ }^{\mathrm{z}}$ Treatments VAM $=$ vesicular arbuscular mycorrhiza, NTC $=$ non tissue culture, $\mathrm{TC}=$ tissue culture, $\mathrm{S} 1=$ seedling with $<3$ tillers; $\mathrm{S} 2=$ seedling with $\geq 3$ tillers. ${ }^{\gamma}$ Within soil additive and seedling type, the values in each column followed by a different letter are significantly different according to LSD at $\mathrm{P} \leq 0.05$. NS, ${ }^{*}{ }^{* *},{ }^{* *}$ Nonsignificant or significant at $\mathrm{P}<0.05,0.01$, and 0.001 , respectively.

Year-one high tunnel study showed that seedling transplant type affected the fresh rhizome yield produced after 5 months. Regardless of origin, the transplant type, TCS2, with three or more tillers, had higher yield than the two S1 types (Table 1). Dry biomass of TCS2 was also higher than that of NTCS1. The superior performance of the TCS2 derived transplants over the S1, regardless of whether tissue culture or not, is as expected. TCS2 plants at transplanting were already in the three-fork stage, the first phase of the grand growth phase as defined by Xizhen et al. [9]. The TCS1 and NTCS1 transplants were still in the seedling stage.

\subsection{Year 2 High Tunnel Study}

One day after transplanting, high tunnel plants were visually observed as healthy. A week later, a few plants in the high tunnel showed a symptom of sun burn, under the high temperatures (Figure 1). The maximum temperatures were mainly above $40^{\circ} \mathrm{C}$, reaching as high as $48.3^{\circ} \mathrm{C}$ during the first month after transplanting. Two weeks after transplanting, the plants appearance looked better following fertilizer application. However, few weeks later and up to a month and half after transplanting (August 16), several plants from all the treatment combinations had some shoots die. During this period, and up to three months after transplanting they continued to periodically experience high maximum temperature above $40^{\circ} \mathrm{C}$. These responses are consistent with the reports of Bhosale and Shinde, and Kandiannan, et al. [10] [32] that ginger grows best at temperatures around $28^{\circ} \mathrm{C}-32^{\circ} \mathrm{C}$, and very high temperatures can be desiccat- 
ing and result in sunburn and plant death. Both high temperature and high light intensity, particularly during the seedling phase, may cause photo inhibition and result in decreased photosynthesis efficiency and yield [9]. The base temperature requirement is $13^{\circ} \mathrm{C}$ [10], and 1200 to 1300 accumulated temperature is required in the growing period [9]. Minimum temperature during our study ranged from $-2^{\circ} \mathrm{C}-2^{\circ} \mathrm{C}$ at harvest to $28.9^{\circ} \mathrm{C}$ during the growing period.

Due to the inconsistency in finding healthy developed leaves for sampling, no LCI data could be sampled for high tunnel or field plants, this year. There was little to no growth in shoot height during this period due to plant dieback and regrowth of new shoots under the high temperatures in the high tunnel (Table 2, Figure 1). Consequently, after plant regrowth, the plant heights for month three were generally less than at the time of transplanting. Mycorrhiza did not affect shoot height or number of tillers, and seedling type did not impact shoot height after transplanting. This lack of response to mycorrhiza application is similar to the results of year one (Table 1) of our study. Although the tillers in the high tunnel grew slowly under the temperature stress in year 2 (Table 2), transplant type still had a significant effect on the number, as in year one (Table 1). The TCS2 consistently produced highest number of tillers. While not significant, rhizome yield per plant trended higher for TCS2 than TCS1 and NTCS1.

\subsection{Field Study}

The data of the field-grown ginger showed no significant differences between soil additives or seedling types for the shoot development and rhizome yield, even though there were differences when they were transplanted (Table 3). The shock due to intense light exposure from direct sunshine and high temperature (Figure 1) quickly wiped out any advantage they had started with in their tiller number or height. One day after transplanting, the leaves of some had sun burn. Three weeks after transplanting (7/5/2012), leaf burn was still observed on some plants. During the first month after transplanting, the maximum temperatures ranged from $25.0^{\circ} \mathrm{C}$ to $38.3^{\circ} \mathrm{C}$ (Figure 1). By month two after transplanting, there were no new leaf burns observed. Maximum temperatures in months two and three after transplanting ranged from $20.6^{\circ} \mathrm{C}-38.3^{\circ} \mathrm{C}$. For the remainder of the study the maximum range was $6.1^{\circ} \mathrm{C}-30.0^{\circ} \mathrm{C}$ (Figure 1); growth remained slow (Table 3), and there were no differences in any of the characteristics measured to test the effects of mycorrhiza or seedling transplant type. Minimum temperature during study ranged from $-0.6^{\circ} \mathrm{C}$ at harvest to $25.6^{\circ} \mathrm{C}$ during the growing period. The study was terminated a week before month five of the growing season due to frost.

The fresh rhizome yield per plant was not significantly affected by mycorrhiza or propagation type (Table 3 ). Across these three studies, the maximum rhizome yield (648 g per plant) five months after transplanting was for the TCS2 derived transplants in year one high tunnel experiment (Table 1). Longer duration studies such as the 10-month field study of Rafie et al. [8] have produced more rhizomes, nearly 5 pounds / plant in the field in Florida, USA. 
Table 2. Effects of soil additive and seedling transplant type on plant height, tiller number and fresh rhizome weight per plant for high tunnel organic ginger development by month (M) after transplanting in 2012.

\begin{tabular}{|c|c|c|c|c|c|c|c|}
\hline \multirow[t]{3}{*}{ Treatment $^{z}$} & \multicolumn{3}{|c|}{ Height } & \multicolumn{3}{|c|}{ Tiller Number (TN) } & \multirow[t]{2}{*}{ Yield/Plant } \\
\hline & M0 & M3 & M4.5 & M0 & M3 & M4.5 & \\
\hline & \multicolumn{3}{|c|}{$\mathrm{cm}$} & \multicolumn{3}{|c|}{$\mathrm{TN}$} & g \\
\hline \multicolumn{8}{|c|}{ Soil additive (SA) } \\
\hline VAM & 20.7 & 15.8 & 23.8 & $2.3 \mathrm{a}$ & 4.0 & 6.7 & 104.7 \\
\hline Control & 19.4 & 15.6 & 22.6 & $2.1 \mathrm{~b}$ & 3.6 & 5.1 & 79.9 \\
\hline SA & NS & NS & NS & NS & NS & NS & NS \\
\hline \multicolumn{8}{|c|}{ Seedling Type (S) } \\
\hline NTCS1 & $24.8 \mathrm{a}^{\mathrm{y}}$ & $13.9 \mathrm{ab}$ & $20.0 \mathrm{a}$ & $1.6 \mathrm{~b}$ & $3.3 \mathrm{~b}$ & $5.0 \mathrm{ab}$ & 72.3 \\
\hline TCS1 & $19.8 \mathrm{~b}$ & $13.7 \mathrm{~b}$ & $21.6 \mathrm{a}$ & $1.8 \mathrm{~b}$ & $3.3 \mathrm{~b}$ & $4.8 \mathrm{~b}$ & 84.3 \\
\hline TCS2 & $15.6 \mathrm{c}$ & $19.6 \mathrm{a}$ & $28.0 \mathrm{a}$ & $3.2 \mathrm{a}$ & $4.9 \mathrm{a}$ & $7.8 \mathrm{a}$ & 120.2 \\
\hline S & $* * *$ & NS & NS & $* * *$ & * & * & NS \\
\hline
\end{tabular}

${ }^{2}$ Treatments VAM = vesicular arbuscular mycorrhiza, NTC = non tissue culture, TC = tissue culture, $\mathrm{S} 1=$ seedling with $<3$ tillers; $\mathrm{S} 2=$ seedling with $\geq 3$ tillers. ${ }^{\gamma}$ Within soil additive and seedling type, the values in each column followed by a different letter are significantly different according to LSD at $\mathrm{P} \leq 0.05$. NS, ${ }^{*},{ }^{* *}$ Nonsignificant or significant at $\mathrm{P}<0.05$, and 0.001 , respectively.

Table 3. Effects of soil additive and seedling transplant type on plant height, tiller number and fresh rhizome weight per plant for ginger development by month (M) after transplanting to organic field in 2012.

\begin{tabular}{|c|c|c|c|c|c|c|c|}
\hline \multirow[t]{3}{*}{ Treatment $^{2}$} & \multicolumn{3}{|c|}{ Height } & \multicolumn{3}{|c|}{ Tiller Number (TN) } & \multirow[t]{2}{*}{ Yield/Plant } \\
\hline & M0 & M3 & M4.5 & M0 & M3 & M 4.5 & \\
\hline & \multicolumn{3}{|c|}{$\mathrm{cm}$} & \multicolumn{3}{|c|}{$\mathrm{TN}$} & g \\
\hline \multicolumn{8}{|c|}{ Soil additive (SA) } \\
\hline VAM & 13.0 & 18.0 & 18.8 & 1.8 & 5.4 & 6.4 & 94.9 \\
\hline Control & 11.9 & 17.5 & 19.2 & 2.0 & 4.7 & 5.7 & 98.4 \\
\hline SA & NS & NS & NS & NS & NS & NS & NS \\
\hline \multicolumn{8}{|c|}{ Seedling Type (S) } \\
\hline NTCS1 & $13.1 \mathrm{ab}^{\mathrm{y}}$ & 17.6 & 21.1 & $1.2 \mathrm{~b}$ & 4.4 & 5.3 & 98.9 \\
\hline TCS1 & $15.7 \mathrm{a}$ & 17.3 & 17.8 & $1.5 \mathrm{~b}$ & 5.0 & 6.1 & 100.6 \\
\hline TCS2 & $9.1 \mathrm{~b}$ & 18.4 & 18.6 & $3.1 \mathrm{a}$ & 5.8 & 6.9 & 90.4 \\
\hline S & $* * *$ & NS & NS & $* * *$ & NS & NS & NS \\
\hline
\end{tabular}

${ }^{2}$ Treatments VAM = vesicular arbuscular mycorrhiza, NTC = non tissue culture, TC = tissue culture, $\mathrm{S} 1=$ seedling with $<3$ tillers; $\mathrm{S} 2=$ seedling with $\geq 3$ tillers. ${ }^{r}$ Within soil additive and seedling type, the values in each column followed by a different letter are significantly different according to LSD at $\mathrm{P} \leq 0.05$. NS, ${ }^{* * *}$ Nonsignificant or significant at $\mathrm{P}<0.001$, respectively.

\subsection{Rhizomes Nutrient Content}

In the 2011 high tunnel study, the following 13 macroelements and trace elements were analyzed for the rhizomes; $\mathrm{N}, \mathrm{S}, \mathrm{P}, \mathrm{K}, \mathrm{Mg}, \mathrm{Ca}, \mathrm{Na}, \mathrm{B}, \mathrm{Zn}, \mathrm{Mg}, \mathrm{Fe}, \mathrm{Cu}$, and $\mathrm{Al}$. The mycorrhiza had no effect on the rhizome content for macroelements and trace elements (Table 4). Except for boron and zinc, transplant seedling type did not affect nutrient content. The NTC transplant derived rhizomes had the highest boron $\left(8.3 \mathrm{mg} \cdot \mathrm{kg}^{-1}\right)$ and zinc $\left(36.8 \mathrm{mg} \cdot \mathrm{kg}^{-1}\right)$. In Year 2 high tunnel 
experiment, calcium level in the control $\left(3.0 \mathrm{~g} \cdot \mathrm{kg}^{-1}\right)$ was higher than in the mycorrhiza treatments, $\left(2.1{\mathrm{~g} \cdot \mathrm{kg}^{-1}}^{-}\right)$(Table 5). In the field study, the boron content of the controls was higher $\left(11.4 \mathrm{mg} \cdot \mathrm{kg}^{-1}\right)$ than that of the mycorrhizae treatments $\left(9.4 \mathrm{mg} \cdot \mathrm{kg}^{-1}\right)$ (Table 6). This nutrient content was also the highest in NTCSI in the 2011 high tunnel study (Table 4). In the field the NTCS1 transplant types had highest copper and boron levels (Table 6). Lead (0.5 - 1.1 $\left.\mathrm{mg} \cdot \mathrm{kg}^{-1}\right)$ and arsenic $\left(0.14-1.1 \mathrm{mg} \cdot \mathrm{kg}^{-1}\right)$ (Table 5 and Table 6) analyzed were within acceptable levels of $10 \mathrm{mg} \cdot \mathrm{kg}^{-1}$ for $\mathrm{Pb}$ and $3.0 \mathrm{mg} \cdot \mathrm{kg}^{-1}$ for As, respectively, for consumption per USA FDA guideline, from Gupta et al. [33]. Macro and trace element content for nutrient levels, were comparable to those from other ginger studies [34].

Table 4. Effects of soil additive and seedling transplant type on nutrient content of organic ginger rhizomes grown in high tunnel in 2011.

\begin{tabular}{|c|c|c|c|c|c|c|c|c|c|c|c|c|c|}
\hline Treatment $^{z}$ & $\mathbf{N}$ & $S$ & $\mathbf{P}$ & $\mathrm{K}$ & $\mathrm{Mg}$ & $\mathrm{Ca}$ & $\mathrm{Na}$ & B & $\mathrm{Zn}$ & $\mathrm{Mn}$ & $\mathrm{Fe}$ & $\mathrm{Cu}$ & $\mathrm{Al}$ \\
\hline & \multicolumn{7}{|c|}{$\mathrm{g} \cdot \mathrm{kg}^{-1}$} & \multicolumn{6}{|c|}{$\mathrm{mg} \cdot \mathrm{kg}^{-1}$} \\
\hline \multicolumn{14}{|l|}{ Soil additive (SA) } \\
\hline VAM & 20.6 & 1.8 & 3.6 & 25.6 & 4.0 & 2.1 & 5.0 & 6.7 & 29.0 & 97.2 & 117.1 & 8.9 & 42.9 \\
\hline Control & 21.7 & 1.9 & 3.6 & 25.6 & 4.1 & 2.2 & 5.7 & 7.4 & 26.7 & 104.7 & 118.3 & 10.0 & 51.6 \\
\hline SA & NS & NS & NS & NS & NS & NS & NS & NS & NS & NS & NS & NS & NS \\
\hline \multicolumn{14}{|l|}{ Seedling Type (S) } \\
\hline NTCS1 & 22.0 & 1.9 & 3.8 & 25.6 & 4.1 & 2.3 & 5.5 & $8.3 a^{y}$ & $36.8 \mathrm{a}$ & 132.3 & 124.0 & 9.7 & 45.5 \\
\hline TCS1 & 21.5 & 1.9 & 3.6 & 24.5 & 4.1 & 2.1 & 5.1 & $6.5 \mathrm{~b}$ & $24.3 \mathrm{~b}$ & 92.0 & 111.0 & 9.2 & 44.3 \\
\hline TCS2 & 20.0 & 1.8 & 3.4 & 26.6 & 4.2 & 2.1 & 5.3 & $6.3 \mathrm{~b}$ & $22.3 \mathrm{~b}$ & 78.5 & 118.2 & 9.5 & 51.8 \\
\hline S & NS & NS & NS & NS & NS & NS & NS & * & $* * *$ & NS & NS & NS & NS \\
\hline
\end{tabular}

${ }^{2}$ Treatments VAM = vesicular arbuscular mycorrhiza, NTC $=$ non tissue culture, $\mathrm{TC}=$ tissue culture, $\mathrm{S} 1=$ seedling with $<3$ tillers; $\mathrm{S} 2=$ seedling with $\geq 3$ tillers. ${ }^{\gamma}$ Within soil additive and seedling type, the values in each column followed by a different letter are significantly different according to LSD at $\mathrm{P} \leq 0.05$. NS, ${ }^{*}{ }^{* *}$ Nonsignificant or significant at $\mathrm{P}<0.05$, and 0.001 , respectively.

Table 5. Effects of soil additive and seedling transplant type on nutrient content of organic ginger rhizomes grown in high tunnel in 2012 .

\begin{tabular}{|c|c|c|c|c|c|c|c|c|c|c|c|c|c|c|c|}
\hline Treatment $^{z}$ & $\mathbf{N}$ & $\mathbf{P}$ & K & $S$ & $\mathrm{Ca}$ & $\mathrm{Mg}$ & $\mathrm{Na}$ & $\mathrm{Fe}$ & $\mathrm{Al}$ & $\mathrm{Mn}$ & $\mathrm{Cu}$ & $\mathrm{Zn}$ & B & As & $\mathrm{Pb}$ \\
\hline & \multicolumn{7}{|c|}{$\mathrm{g} \cdot \mathrm{kg}^{-1}$} & \multicolumn{8}{|c|}{$\mathrm{mg} \cdot \mathrm{kg}^{-1}$} \\
\hline \multicolumn{16}{|c|}{ Soil additive (SA) } \\
\hline VAM & 18.5 & 3.0 & 25.5 & 2.5 & $2.1 \mathrm{~b}^{\mathrm{y}}$ & 3.5 & 5.5 & 109.9 & 43.6 & 71.3 & 6.6 & 25.5 & 7.9 & 0.16 & 0.95 \\
\hline Control & 21.4 & 3.8 & 31.8 & 2.9 & $3.0 \mathrm{a}$ & 4.2 & 7.3 & 115.6 & 42.5 & 97.7 & 7.4 & 28.8 & 9.3 & 0.26 & 1.1 \\
\hline SA & NS & NS & NS & NS & * & NS & NS & NS & NS & NS & NS & NS & NS & NS & NS \\
\hline \multicolumn{16}{|c|}{ Seedling Type (S) } \\
\hline NTCS1 & 20.0 & 3.4 & 27.0 & 2.7 & 2.4 & 3.7 & 5.6 & 114.3 & 49.0 & 102.3 & 7.3 & 28.3 & 8.9 & 0.14 & 1.07 \\
\hline TCS1 & 19.8 & 3.3 & 30.6 & 2.6 & 2.4 & 3.7 & 5.9 & 104.4 & 37.8 & 92.1 & 6.8 & 26.7 & 7.9 & 0.24 & 0.92 \\
\hline TCS2 & 20.2 & 3.5 & 28.3 & 2.8 & 2.7 & 4.1 & 7.6 & 119.5 & 44.7 & 59.0 & 7.0 & 26.5 & 9.1 & 0.24 & 1.03 \\
\hline S & NS & NS & NS & NS & NS & NS & NS & NS & NS & NS & NS & NS & NS & NS & NS \\
\hline
\end{tabular}

${ }^{2}$ Treatments VAM = vesicular arbuscular mycorrhiza, NTC $=$ non tissue culture, TC = tissue culture, $\mathrm{S} 1=$ seedling with $<3$ tillers; $\mathrm{S} 2=$ seedling with $\geq 3$ tillers. ${ }^{\gamma}$ Within soil additive and seedling type, the values in each column followed by a different letter are significantly different according to LSD at $\mathrm{P} \leq 0.05$. NS, ${ }^{*}$ Nonsignificant or significant at $\mathrm{P}<0.05$, respectively. 
Table 6. Effects of soil additive and seedling transplant type on nutrient content of organic ginger rhizomes grown in field in 2012 .

\begin{tabular}{|c|c|c|c|c|c|c|c|c|c|c|c|c|c|c|c|}
\hline Treatment $^{z}$ & $\mathbf{N}$ & $\mathbf{P}$ & $\mathrm{K}$ & $S$ & $\mathrm{Ca}$ & $\mathrm{Mg}$ & $\mathrm{Na}$ & $\mathrm{Fe}$ & $\mathrm{Al}$ & Mn & $\mathrm{Cu}$ & $\mathrm{Zn}$ & B & As & $\mathrm{Pb}$ \\
\hline & \multicolumn{7}{|c|}{$\mathrm{g} \cdot \mathrm{kg}^{-1}$} & \multicolumn{8}{|c|}{$\mathrm{mg} \cdot \mathrm{kg}^{-1}$} \\
\hline \multicolumn{16}{|c|}{ Soil additive (SA) } \\
\hline VAM & 18.0 & 4.4 & 33.3 & 2.3 & 2.4 & 5.4 & 3.2 & 124.3 & 38.7 & 127.7 & 7.6 & 37.2 & $9.4 \mathrm{~b}^{\mathrm{z}}$ & 0.9 & 0.6 \\
\hline Control & 19.3 & 5.3 & 43.7 & 2.4 & 2.7 & 5.4 & 5.5 & 115.4 & 24.1 & 139.6 & 7.5 & 41.5 & $11.4 \mathrm{a}$ & 1.1 & 0.6 \\
\hline SA & NS & NS & NS & NS & NS & NS & NS & NS & NS & NS & NS & NS & * & NS & NS \\
\hline \multicolumn{16}{|l|}{ Seedling Type (S) } \\
\hline NTCS1 & 21.0 & 5.2 & 38.9 & 2.5 & 3.0 & 5.7 & 5.3 & 126.4 & 42.3 & 170.5 & $10.4 \mathrm{a}$ & 44.0 & $12.6 \mathrm{a}$ & 0.9 & 0.6 \\
\hline TCS1 & 18.1 & 4.8 & 40.2 & 2.2 & 2.3 & 5.1 & 3.8 & 113.9 & 23.3 & 127.6 & $6.3 \mathrm{~b}$ & 35.3 & $9.3 \mathrm{~b}$ & 0.9 & 0.5 \\
\hline TCS2 & 17.0 & 4.6 & 36.8 & 2.3 & 2.5 & 5.2 & 4.0 & 119.4 & 28.7 & 102.7 & $6.0 \mathrm{~b}$ & 38.7 & $9.3 \mathrm{~b}$ & 1.1 & 0.7 \\
\hline S & NS & NS & NS & NS & NS & NS & NS & NS & NS & NS & $* *$ & NS & ** & NS & NS \\
\hline
\end{tabular}

${ }^{2}$ Treatments VAM = vesicular arbuscular mycorrhiza, NTC = non tissue culture, TC = tissue culture, $\mathrm{S} 1=$ seedling with $<3$ tillers; $\mathrm{S} 2=$ seedling with $\geq 3$ tillers. ${ }^{r}$ Within soil additive and seedling type, the values in each column followed by a different letter are significantly different according to LSD at $\mathrm{P} \leq 0.05$. NS, ${ }^{*}{ }^{* *}$ Nonsignificant or significant at $\mathrm{P}<0.05$, and 0.01 , respectively.

\section{Conclusion}

This study shows that using ginger transplant seedlings in more advanced stage with more tillers, such as TCS2, provides an advantage in supporting more tiller growth over types at lower developmental stages like the TCS1 and NTCS1. However, the use of established soil biological amendments such as mycorrhiza was not effective in enhancing ginger growth in the short season. Introducing ginger production in temperate region, such as the Delmarva Peninsula of the USA, has some limitations where the short growing season, high light intensity outdoors, particularly at transplanting, and periodic summer heat waves may occur. While dieback and regrowth will occur, after exposure to such conditions, the resulting stunting of plant will decrease the potential to produce more rhizomes as indicated in this study. This distress may potentially be averted through shading, a practice used in many ginger producing areas; transplanting earlier, by May 15 when warm temperatures occur and are typically not as high as summer; and or using other practices that will ameliorate temperature build-up in the growing environment. The rhizomes produced from our study had nutrient contents that fell within acceptable levels for them to be safely consumed.

\section{Acknowledgements}

This research was supported by USDA NIFA-Evans Allen funds through the University of Maryland Eastern Shore Experiment Station.

\section{Conflicts of Interest}

The authors declare no conflicts of interest regarding the publication of this paper. 


\section{References}

[1] Ravindran, P.N. and Nirmal Babu, K. (2005) Ginger the Genus Zingiber. C.H.I.P.S., Weimar, TX.

[2] Zhang, M., Xiao, B., Wang, H., et al. (2016) Edible Ginger-Derived Nano-Lipids Loaded with Doxorubicin as a Novel Drug-Delivery Approach for Colon Cancer Therapy. Molecular Therapy, 24, 1783-1796. https://doi.org/10.1038/mt.2016.159

[3] Singh, M., Khan, M.M.A., Moinuddin and Naeem, M. (2012) Augmentation of Nutraceuticals, Productivity and Quality of Ginger (Zingiber officinale Rosc.) through Triacontanol Application. Plant Biosystems, 146, 106-113. https://doi.org/10.1080/11263504.2011.575891

[4] Sideman, B. (2018) Effects of Early Season Heating, Low Tunnels, and Harvest Time on Ginger Yields in NH, 2017. UNH Cooperative Extension. https://extension.unh.edu/resources/files/Resource007161 Rep10344.pdf

[5] Rafie, R., Nartea, T. and Mullins, C. (2012) Growing High Tunnel Ginger in High Tunnels: A Niche Crop with Market Potential. Proceedings Florida State Horticulture, 125, 142-143.

[6] Stephens, J.M. (2018) Ginger-Zingiber officinale Roscoe. University of Florida. http://edis.ifas.ufl.edu/pdffiles/MV/MV06700.pdf

[7] Ernst, M. and Durbin, K. (2019) Ginger and Turmeric. CCD-CP-138. Center for Crop Diversification, University of Kentucky College of Agriculture, Food and Environment, Lexington.

http://www.uky.edu/ccd/sites/www.uky.edu.ccd/files/ginger turmeric.pdf

[8] Rafie, A.R., Teresa, O. and Guerrero, W. (2003) Hydroponic Production of Fresh Ginger Roots (Zingiber officinale) as an Alternative Method for South Florida. Proceedings of Florida State Horticulture Society, 116, 51-52.

[9] Ai, X.Z., Song, J.F. and Xu, X. (2005) Ginger Production in Southeast Asia. In: Ravindran, P.N. and Nirmal Babu, K., Eds., Ginger. The Genus Zingiber, Medicinal and Aromatic Plants-Industrial Profiles, CRC Press, Boca Raton, 241-278.

[10] Kandiannan, K., Sivaraman, K., Thankamani, C.K. and Peter, K.V. (1996) Agronomy of Ginger (Zingiber officinale Rosc.). Journal of Spices and Aromatic Crops, 5 , $1-27$.

[11] USDA Economic Research Service (2019) Organic Market Overview. http://www.ers.usda.gov/topics/natural-resources-environment/organic-agriculture lorganic-market-overview.aspx

[12] Prasath, D., Kandiannan, K., Srinivasan, V., Leela, N.K. and Anandaraj, M. (2018) Comparison of Conventional and Transplant Production Systems on Yield and Quality of Ginger (Zingiber officinale Rosc.). Indian Journal of Agricultural Sciences, 88, 615-620.

[13] Sanwal, S.K., Yadav, R.K. and Singh, P.K. (2007) Effect of Types of Organic Manure on Growth, Yield and Quality Parameters of Ginger (Zingiber officinale). Indian Journal of Agricultural Sciences, 77, 67-72.

[14] Nongmaithem, J., Ghosh, M., Ghosh, D.C., Meitei, W.I. and Timsina, J. (2013) Effect of Biofertilizer on Growth, Productivity, Quality and Economics of Rainfed Organic Ginger (Zingiber officinale Rosc.) Bhaisey cv. in North-Eastern Region of India. Journal of Agricultural. Science and Technology, 3, 83-98.

[15] Verma, V. K., Patel, R.K, Deshmukh, N.A., Jha, A.K., Ngachan, S.V., Singha, A.K. and Deka, B.C. (2019) Response of Ginger and Turmeric to Organic Versus Traditional Production Practices at Different Elevations under Humid Subtropics of 
North-Eastern India. Industrial Crops and Products, 136, 21-27. https://doi.org/10.1016/j.indcrop.2019.04.068

[16] Santos, R.D., Girardi, C.G., Pescador, R. and Stürmer, S.L. (2010) Effects of Arbuscular Mycorrhizal Fungi and Phosphorus Fertilization on Post Vitro Growth of Micropropagated Zingiber officinale Roscoe. Revista Brasileira de Ciência do Solo, 34, 765-771. https://doi.org/10.1590/S0100-06832010000300018

[17] Samanhudi, Yunus, A., Pujiasmanto, A.B. and Rahayu, M. (2014) Effect of Organic Manure and Arbuscular Mycorrhizal Fungi on Growth and Yield of Young Ginger (Zingiber officinale Rosc.). Journal of Agriculture and Veterinary Science, 7, 1-5. https://doi.org/10.9790/2380-07540105

[18] De Pascale, S., Rouphael, Y. and Colla, G. (2017) Plant Biostimulants: Innovative Tool for Enhancing Plant Nutrition in Organic Farming. European Journal of Horticultural Science, 82, 277-285. https://doi.org/10.17660/eJHS.2017/82.6.2

[19] Khan, A., Ding, Z., Ishaq, M., Khan, I., Ahmed, A.A., Khan, A.Q. and Guo, X. (2020) Applications of Beneficial Plant Growth Promoting Rhizobacteria and Mycorrhizae in Rhizosphere and Plant Growth: A Review. International Journal of Agricultural and Biological Engineering, 13, 199-208.

https://doi.org/10.25165/j.ijabe.20201305.5762

[20] Pylak, M., Oszust, K. and Frąc, M. (2019) Review Report on the Role of Bioproducts, Biopreparations, Biostimulants and Microbial Inoculants in Organic Production of Fruit. Reviews in Environmental Science and Biotechnology, 18, 597-616. https://doi.org/10.1007/s11157-019-09500-5

[21] Wright, S.F., Frank-Snyder, M., Morton, J.B. and Upadhyaya, A. (1996) Time-Course Study and Partial Characterization of Protein on Hyphae of Arbuscular Mycorrhizal Fungi during Active Colonization of Roots. Plant and Soil, 181, 193-203. https://doi.org/10.1007/BF00012053

[22] Wu, Q.S., Cao, M.Q., Zou, Y.N. and He, X.H. (2014) Direct and Indirect Effects of Glomalin, Mycorrhizal Hyphae, and Roots on Aggregate Stability in Rhizosphere of Trifoliate Orange. Scientific Reports, 4, Article No. 5823. https://doi.org/10.1038/srep05823

[23] Smith, M.K. and Hamill, S.D. (1996) Field Evaluation of Micropropagated and Conventionally Propagated Ginger in Subtropical Queensland. Australian Journal of Experimental Agriculture, 36, 347-354. https://doi.org/10.1071/EA9960347

[24] Jo, M.H., Ham, I.K., Lee, M.A., Park, S.K. and Kwon, K.H. (2007) Efficient Production of Rhizome Induced by Tissue Culture in Ginger (Zingiber officinale Roscoe). Acta Horticulture, 764, 271-274. https://doi.org/10.17660/ActaHortic.2007.764.36

[25] Lincy, A.K., Remashree, A.B. and Sasikumar, B. (2004) Direct Multiple Shoot Induction from Aerial Stems of Ginger ( $Z$. officinale). Journal of Applied Horticulture, 6, 99-101. https://doi.org/10.37855/jah.2004.v06i02.21

[26] MDA (2009) Navigating the National Organic Program (NOP). http://mda.maryland.gov/foodfeedquality/Documents/navigating nop.pdf

[27] Silva, M.F.D., Pescador, R., Rebelo, R.A. and Stürmer, S.L. (2008) The Effect of Arbuscular Mycorrhizal Fungal Isolates on the Development and Oleoresin Production of Micropropagated Zingiber officinale. Brazilian Journal of Plant Physiology, 20, 119-130. https://doi.org/10.1590/S1677-04202008000200004

[28] Stewart, L.I., Hamel, C., Hogue, R. and Moutoglis, P. (2005) Response of Strawberry to Inoculation with Arbuscular Mycorrhizal Fungi under Very High Soil Phosphorus Conditions. Mycorrhiza, 15, 612-619. https://search.proquest.com/docview/925398829?accountid=14579 
https://doi.org/10.1007/s00572-005-0003-Z

[29] Loh, F.C.W., Grabosky, J.C. and Bassuk, N.L. (2002) Using the SPAD 502 Meter to Assess Chlorophyll and Nitrogen Content of Benjamin Fig and Cottonwood Leaves. HortTechnology, 12, 682-686. https://doi.org/10.21273/HORTTECH.12.4.682

[30] Evans, J.R. (1983) Nitrogen and Photosynthesis in the Flag Leaf of Wheat. Plant Physiology, 72, 297-302. https://doi.org/10.1104/pp.72.2.297

[31] Seeman, J.R., Sharkey, T.J., Wang, J. and Osmond, C.B. (1987) Environmental Effects on Photosynthesis, Nitrogen-Use Efficiency and Metabolic Pools in Leaves of Sun and Shade Plants. Plant Physiology, 84, 796-802.

https://doi.org/10.1104/pp.84.3.796

[32] Bhosale, K.S. and Shinde, B. (2011) Influence of Arbuscular Mycorrhizal Fungi on Proline and Chlorophyll Content in Zingiber officinale Rosc Grown under Water Stress. Indian Journal of Fundamental and Applied Life Sciences, 1, 172-176.

[33] Gupta, S., Pandotra, P., Gupta, A.P., Dhar, J.K., Sharma, G., Ram, G., Husain, M.K. and Bedi, Y.S. (2010) Volatile (As and $\mathrm{Hg}$ ) and Non-Volatile ( $\mathrm{Pb}$ and $\mathrm{Cd}$ ) Toxic Heavy Metals Analysis in Rhizome of Zingiber officinale Collected from Different Locations of North Western Himalayas by Atomic Absorption Spectroscopy. Food and Chemical Toxicology, 48, 2966-2971. https://doi.org/10.1016/j.fct.2010.07.034

[34] Wagesho, Y. and Chandravanshi, B.S. (2015) Levels of Essential and Non-Essential Metals in Ginger (Zingiber officinale) Cultivated in Ethiopia. SpringerPlus, 4, Article No. 107. https://doi.org/10.1186/s40064-015-0899-5 